\title{
Refuge
}

Canada's Journal on Refugees

revue canadienne sur les réfugiés

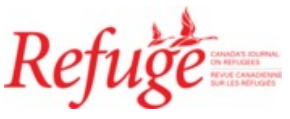

\section{Decade of Despair: The Contested Rebuilding of the Nahr al-Bared Refugee Camp, Lebanon, 2007-2017}

\section{Are John Knudsen}

Volume 34, numéro 2, 2018

URI : https://id.erudit.org/iderudit/1055584ar

DOI : https://doi.org/10.7202/1055584ar

Aller au sommaire du numéro

Éditeur(s)

Centre for Refugee Studies, York University

ISSN

0229-5113 (imprimé)

1920-7336 (numérique)

Découvrir la revue

Citer cet article

Knudsen, A. (2018). Decade of Despair: The Contested Rebuilding of the Nahr al-Bared Refugee Camp, Lebanon, 2007-2017. Refuge, 34(2), 135-149.

https://doi.org/10.7202/1055584ar
Résumé de l'article

À la mi-2007, le camp de réfugiés de Nahr al-Bared a été détruit par l'armée libanaise alors qu'elle combattait Fatah al-Islam, un groupe de rebelles islamistes. Ce confit, l'un des confits internes les plus importants après la guerre civile libanaise, a déplacé environ 30000 réfugiés palestiniens. Dix ans plus tard, le camp reste encore à reconstruire entièrement ; en réalité, sa reconstruction est lente, confictuelle et insufsamment financée. Cette reconstruction est contestée et retardée par une opposition politique, par un manque de fonds, et par des problèmes complexes de propriété foncière et patrimoniale. Aujourd'hui, environ la moitié des familles déplacées ont pu retourner au camp, l'autre moitié restant déplacée à l'intérieur du pays, vivant de manière temporaire dans d'autres camps ou dans des appartements loués. Cet article analyse la lente reconstruction du camp de Nahr al-Bared, et tout particulièrement les enseignements qui peuvent être tirés quant au relogement des réfugiés dans un espace militarisé d'exception.
Copyright (c) Refuge: Canada’s Journal on Refugees, 2018

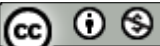

Ce document est protégé par la loi sur le droit d'auteur. L’utilisation des services d’Érudit (y compris la reproduction) est assujettie à sa politique d'utilisation que vous pouvez consulter en ligne. 


\title{
Decade of Despair: The Contested Rebuilding of the Nahr al-Bared Refugee Camp, Lebanon, 2007-2017
}

\author{
ARE JOHN KNUDSEN
}

\section{Abstract}

In mid-2007 the Nahr al-Bared refugee camp near Tripoli was destroyed by the Lebanese Army battling an insurgent Islamist group, Fatah al-Islam. Displacing about 30,000 Palestinian refugees, it was one of the largest internal battles in post-civil war Lebanon. A decade later, the camp has yet to be fully rebuilt; indeed, reconstruction has been slow, conflictual, and underfunded. Rebuilding the camp has been contested and delayed by political opposition, funding shortfalls, and complex ownership of land and property. About half of the displaced families have been able to return, the remainder are internally displaced, living temporarily in other camps or rented apartments. This article analyzes the slow-paced reconstruction of the Nahr al-Bared camp and especially what can be learnt from rehousing refugees in a militarized space of exception.

\section{Résumé}

À la mi-2007, le camp de réfugiés de Nahr al-Bared a été détruit par l'armée libanaise alors quelle combattait Fatah al-Islam, un groupe de rebelles islamistes. Ce conflit, l'un des conflits internes les plus importants après la guerre civile libanaise, a déplacé environ 30 ooo réfugiés palestiniens. Dix ans plus tard, le camp reste encore à reconstruire entièrement; en réalité, sa reconstruction est lente, conflictuelle et insuffisamment financée. Cette reconstruction est contestée et retardée par une opposition politique, par un manque de fonds, et par des problèmes complexes de propriété foncière et patrimoniale. Aujourd'hui, environ la moitié des familles déplacées ont pu retourner au camp, l'autre moitié restant déplacée à l'intérieur du pays, vivant de manière temporaire dans d'autres camps ou dans des appartements loués. Cet article analyse la lente reconstruction du camp de Nahr al-Bared, et tout particulièrement les enseignements

Cette ouvre en libre accès fait l'objet d'une licence Creative Commons Attribution-NonCommercial 4.0 International License, laquelle autorise l'utilisation, la reproduction et la distribution de l’euvre sur tout support à des fins non commerciales, pourvu que l'auteur ou les auteurs originaux soient mentionnés et que la publication originale dans Refuge: revue canadienne sur les réfugiés soit citée. 
qui peuvent être tirés quant au relogement des réfugiés dans un espace militarisé d'exception.

\section{Introduction}

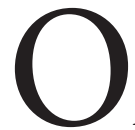
n 20 May 2007, after weeks of minor skirmishes, heavy fighting broke out between the Lebanese Army and Fatah al-Islam, a militant Islamist group that had infiltrated the Nahr al-Bared camp near Tripoli (figure 1). After fifteen weeks of intense bombardment and gunfire, the camp was reduced to rubble and the death toll had reached 500, including around 226 militants and 179 soldiers. ${ }^{1}$ At least 50 civilians were also killed in the bloody standoff that forced the camp's 30,000 residents to flee, most of them to the Beddawi refugee camp located ten kilometres to the south, doubling the camp's population. This was one of the biggest internal conflict events since end of the civil war in 1990. Following in the wake of nationwide political crisesthe 2005 assassination of former premier Rafik Hariri and the 2006 July War with Israel-the battle turned into a proxy war between pro-Syrian and pro-Western government blocs. ${ }^{2}$

Cautious of being drawn into an urban street fight in the alleyways of the camp, the army resorted to mortar fire and aerial bombardment of the camp. ${ }^{3}$ The sustained bombing accounted for the enormous physical destruction of the Nahr al-Bared camp. ${ }^{4}$ Almost 6,000 residential and commercial units were damaged or destroyed, as was the camp's rudimentary infrastructure: electricity, water, and sewage. 5 The army's siege trapped civilians inside the camp, ignoring calls for a truce by humanitarian groups. The last civilians were evacuated from the camp in late August, more than two months after the battle began. In September, after more than one hundred days of sustained bombing, the last Fatah al-Islam fighters were defeated and the remaining 215 militiamen taken into custody. ${ }^{6}$ Palestinian officials from Hamas and the Palestine Liberation Organization (PLO) differed in their response to the army's siege of the camp but, fearing reprisals against the refugees, chose to protect the residents at the expense of the camp.7 Lacking protection from political patrons, the camp could be destroyed without consequence. The Nahr al-Bared residents were a marginal and isolated minority that could be marked out as disposable; indeed, only in a refugee camp would a humanitarian disaster be hailed as a victory. ${ }^{8}$

One of the first refugee camps to be established by the United Nations Relief and Works Agency for Palestine Refugees in the Near East (UNRWA), the tiny Nahr al-Bared camp began in 1949 as a tented settlement that later was replaced by breeze-bloc sheds and houses (figure 2). By the 1950s, Nahr al-Bared was one of fifteen official refugee camps, ${ }^{9}$ which were later reduced to twelve when three ruined camps were not rebuilt after the civil war (1975-90).
In 1983 the Nahr al-Bared camp was destroyed by interfactional battles, but there was no concerted post-war effort to rebuild the camp or other camps, and they were haphazardly rebuilt as money and resources allowed. ${ }^{10}$ In 1986 the Shatila refugee camp in south Beirut was ruined by the factional infighting that became known as the "War of the Camps." The destitute residents were given individual grants for reconstruction, but without any plan or coordinating body to steer reconstruction. ${ }^{11}$ Unplanned and underfunded reconstruction has made refugee camps like Shatila remain overcrowded slums, ${ }^{12}$ without proper sewage, water, and electricity infrastructure. ${ }^{13}$ There is no historical precedent for the systematic rebuilding of refugee camps destroyed by war in Lebanon.

Programs that seek to refurbish, upgrade, or improve dilapidated Palestinian refugee camps are typically met with suspicion, as they are seen as a potential threat to the refugees' "right of return [to Palestine]" as attested by case studies from the Jordan valley and Syria. ${ }^{14}$ This problem becomes even more acute when a refugee camp is not only upgraded, but rebuilt after being purposively destroyed. An example is Linda Tabar's study of the rebuilding of the West Bank Jenin refugee camp ravaged by Israeli bulldozers in 2002. ${ }^{15}$ The reconstruction of Jenin's ruined centre and rebuilding the 500 destroyed houses took three years and was contested among residents in the camp and vis-à-vis UNRWA. The camp's stakeholder committee wanted to rebuild the camp "as it was" and it was adamant that the new access roads should replicate the narrow streets of the old centre as a means of community protection. This demand brought the committee into conflict with UNRwA planners, who argued that narrow roads were neither feasible nor desirable. UNRWA's vision for unhindered vehicular access was shared by other residents viewing wide access roads as preferable, despite legitimate security concerns. The disagreement delayed planning and divided residents. In the end, the committee was sidelined, and the proponents were branded "emotional," "self-interested," and therefore "political," as opposed to UNRWA's masterplan cast as neutral and universal. ${ }^{16}$ UNRWA pushed through with the plan for seven-metre roads, almost twice the maximum demanded by the committee and three times wider than the pedestrian footpaths. The contested reconstruction of the Jenin camp prefigured UnRwA's Camp Improvement Program, which was inaugurated in 2006 and aimed at "improving living conditions in houses and camps through a systematic and participatory approach."17 The new program incorporated lessons from Jenin (West Bank) and Neirab (Syria) and marked a transition from relief to development. The new program replaced UNRWA's outdated housing and shelter standards with a new policy that ruined homes should be rebuilt on the basis of 


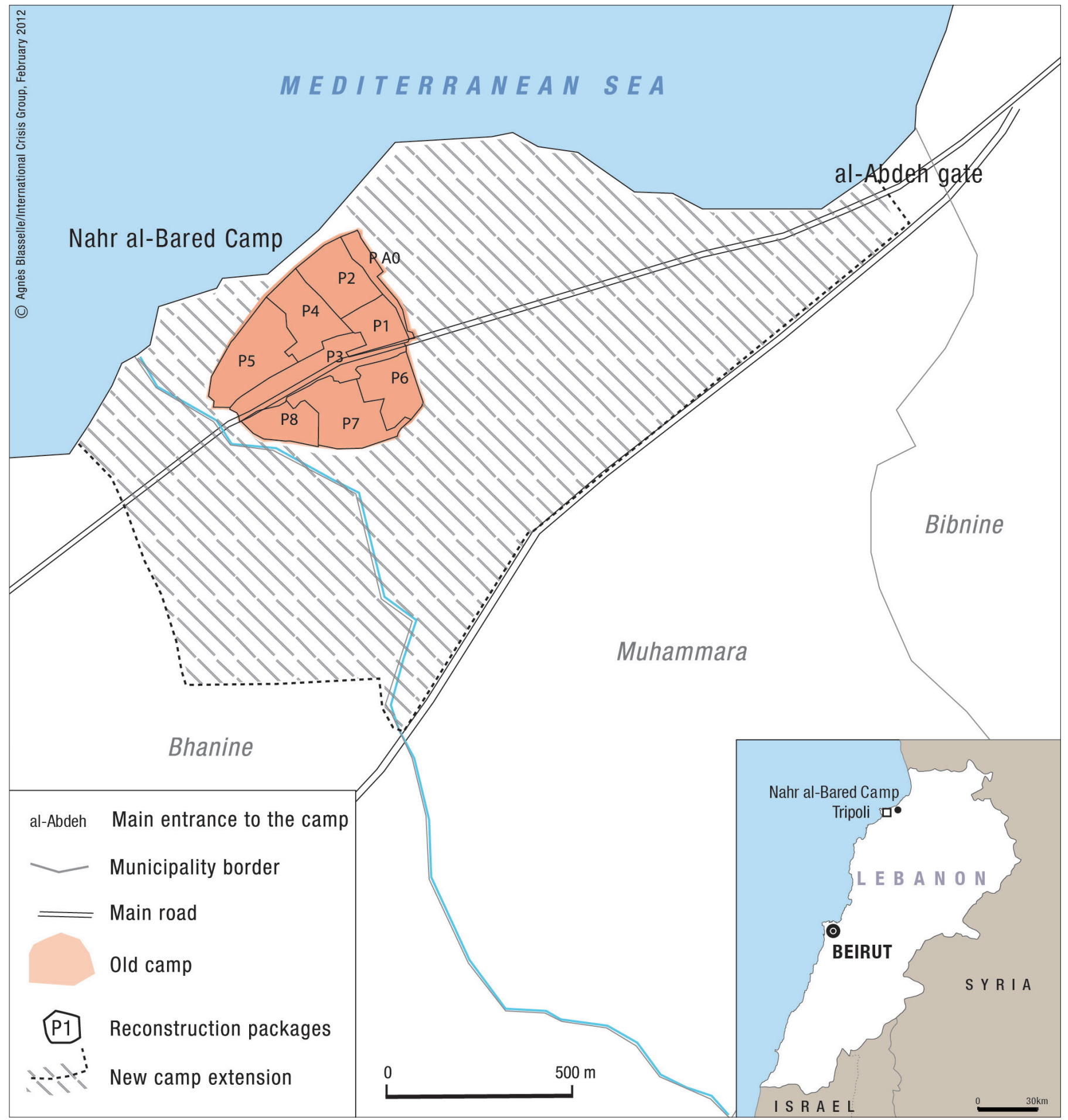

Figure 1. Nahr al-Bared refugee camp, inset map of Lebanon

(C) ICG. Reproduced with permission from International Crisis Group, Middle East Report, no. 117, 1 March 2012. https://d2071andvipowj .cloudfront.net/117-lebanon-s-palestinian-dilemma-the-struggle-over-nahr-al-bared.pdf.

what was lost. ${ }^{18}$ Nonetheless, camp upgrading and improvement programs continued to stir conflict, amidst internal divisions and claims of elite hijacking of projects. ${ }^{19}$

\section{Exceptionality of Camps}

In recent years the works of Giorgio Agamben have attracted attention to the unique governance issues that produce 


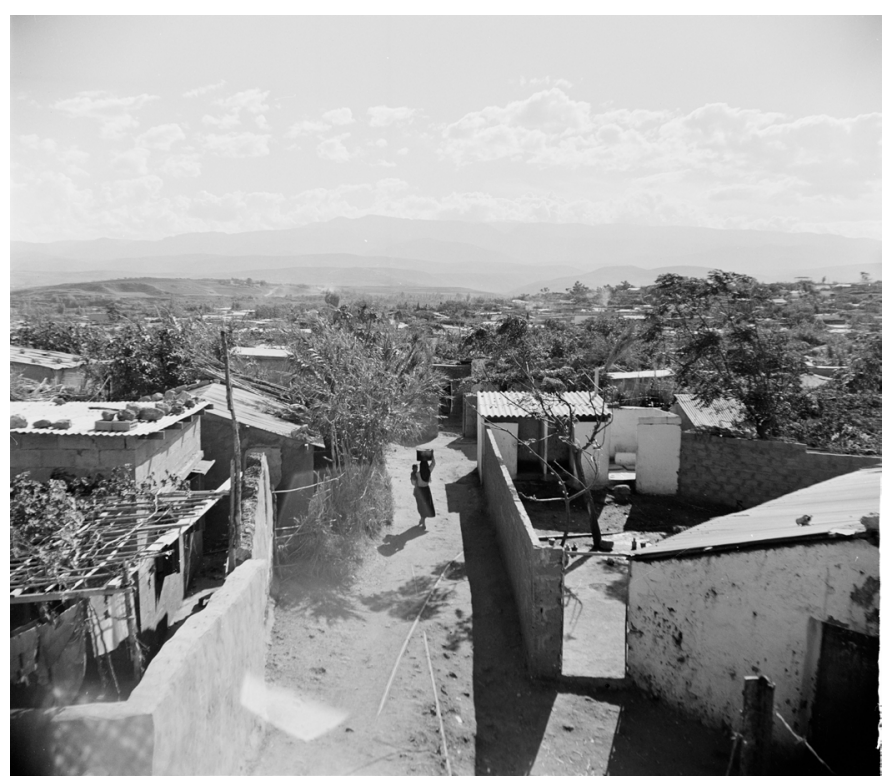

Figure 2. Nahr al-Bared, ca. 1960

(c) UNRWA. Reproduced with permission by the United Nations Relief and Works Agency for Palestine Refugees in the Near East (UNRWA) under licence agreement signed 31 October 2018 between the author and UNRWA.

refugee camps as "spaces of exception" and turn resident refugees into disposable subalterns ("bare life"). ${ }^{20}$ Despite the emerging critique of Agamben ${ }^{21}$ and the sometimes simplified and over-determined use of his key concepts, in Lebanon his work has been used to deconstruct camp governance, ${ }^{22}$ detainment refugees and wholesale destroy camps wholesale, ${ }^{23}$ but not to explain the complex and contested refurbishing and rebuilding of refugee camps. This omission is significant, because it is in their reconstruction, I contend, that the inherit contradictions of refugee camps are most glaring. To this end, this article is a contribution to the discussion of the exceptionality of refugee camps ${ }^{24}$ and here used to analyze the conditions that make rebuilding refugee camps a quagmire. Punitive house demolitions is a common form of collective punishment of Palestinians, ${ }^{25}$ making analyzing it particularly important for urban planning, and especially so because of the importance of home for exiled Palestinians, captured in the multi-vocal Arabic term al-Beit. ${ }^{26}$

The exceptionality of refugee camps becomes even more glaring when we compare this to the rebuilding of non-camp urban and rural neighbourhoods destroyed by war. In mid2006, Hizbollah's cross-border ambush of an Israeli patrol led to a month-long military campaign known as the "July War" with punitive Israeli air strikes targeting Shia-majority areas in South Lebanon and Beirut's Southern Suburbs (Haret
Hreik) and wreaking destruction of residential areas (table 1). ${ }^{27}$ Within hours of the United Nations brokered ceasefire, Hizbollah's reconstruction wing Jihad al-Bina delivered cash grants directly to the affected home-owners in the South, soon followed by other Arab and Muslim donors providing grants ranging from US $\$ 3,000$ to US $\$ 30,000 .{ }^{28}$ Providing cash grants to affected homeowners played on local sentiments where speed and efficiency trumped other concerns. ${ }^{29}$ This gave the Arab donors strong popular credibility, unlike Western donors favouring a governmental response, which was interpreted as propping up the state in a country where the government is associated with a slow, wasteful, and corrupt bureaucracy. A reconstruction facilitator rather than actor, ${ }^{30}$ the Government of Lebanon (GoL) paid the least and was slowest in disbursing funds. ${ }^{31}$ In addition to emergency aid and cash grants to the affected villages and homeowners, the many foreign donors also provided massive bilateral support to Lebanon that was chartered both inside (Saudi Arabia) and outside government-controlled channels (Iran, Jihad al-Bina), reflecting donor agendas and political relations vis-à-vis the Government of Lebanon $(\mathrm{GoL}) .^{32}$

The importance of rapid rebuilding and rehousing of residents was also key to Hizbollah's reconstruction in Beirut's Haret Hreik neighbourhood where 20,000 destitute homeowners (malikeen) were rehoused by Waad, a subsidiary of Hizbollah's reconstruction agency (Jihad al-Bina) tasked with planning the reconstruction of Haret Hreik. A not-for-profit NGO, Wa'ad was named after General Secretary Hassan Nasrallah's "solemn promise" (Wa'ad al-Sadiq) to rebuild homes "more beautiful than before." As the legal representative of the homeowners, ${ }^{33}$ Wa'ad collected the government compensation funds on their behalf, disregarding calls from urban planners to provide more public space that would delay the reconstruction, ${ }^{34}$ rebuilt the 300 multistory houses as pre-war replicas within five years (table 1). 35 To this end the design, planning, and reconstruction were chartered outside state channels and made the Hizbollah an "urban planner." 36

In little more than two years (2006-8), almost two-thirds of the buildings damaged or destroyed in South Lebanon had been either rehabilitated or rebuilt, and more than three-quarters of the displaced had returned home (table 1). In Haret Hreik the level of destruction and size of displacement was comparable to Nahr al-Bared but covered a much larger area; 37 reconstruction and rehousing the residents was completed in five years (table 1). In 2008 UnRwA estimated that rebuilding the Nahr al-Bared camp would take three years,,$^{38}$ but a decade later only half of the destroyed homes had been rebuilt and the majority had not returned. This comparison demonstrates that UNRWA achieved less in ten years than the July War actors in less than half this time 
Table 1. Comparison of conflict events, costs, and reconstruction outcomes, 2007-17

\begin{tabular}{|c|c|c|c|c|c|c|c|}
\hline $\begin{array}{l}\text { Conflict } \\
\text { event }\end{array}$ & $\begin{array}{l}\text { Reconstruc- } \\
\text { tion period }\end{array}$ & $\begin{array}{r}\text { Pledged } \\
\text { US\$ } \\
\text { (millions) }\end{array}$ & $\begin{array}{r}\text { Disbursed } \\
\text { US\$ } \\
\text { (millions) }\end{array}$ & $\begin{array}{l}\text { Residential } \\
\text { units ruined }\end{array}$ & $\begin{array}{l}\text { Residential } \\
\text { units rebuilt }\end{array}$ & IDPs & $\begin{array}{l}\text { Rehoused \& } \\
\text { returned (\%) }\end{array}$ \\
\hline $\begin{array}{l}\text { Nahr al- } \\
\text { Bared siege }\end{array}$ & 2007-17 & 345 & $238^{d}$ & 4,591 & 2,514 & 20,000 & 54 \\
\hline
\end{tabular}

a. Data collated from Al-Harithy (2010), Barakat and Zyck (2010); Barakat (2013); Mac Ginty and Hamieh (2010); GoL (2008); Hourani (2015); UNRWA.org (2017); UNRWA (2018).

b. Arab and Muslim donors (US\$622 million), GoL (US\$293 million), Jihad al-Bina (US\$600 million).

c. The homeowners were paid US\$50,000 each, plus additional compensation for "common areas" (US\$30,000). Support from Jihad al-Bina other donors (Iran) accounted for the rest.

d. Of the twenty-seven donors, the three largest are United States (US\$85 million), Saudi Arabia (US\$50 million) and EU (US\$41 million). The Palestine Liberation Organization (PLO) donated US\$2.2 million, which is higher than the median donor support.

(table 1). What are the reasons that rebuilding the tiny Nahr al-Bared camp took so long and proved so difficult?

In this article I argue that the contested Nahr al-Bared reconstruction was delayed in response to lessons from the July War's rapid reconstruction and rehousing projects. The slow-paced reconstruction took place inside bureaucratic governance channels, hence was subject to political bickering and delays. The design principles were contested, planning was politicized, and the contractor-driven reconstruction stewarded by a humanitarian relief agency (UNRwA) depended on donations. Blamed for hosting a militant Islamist group, the displaced Nahr al-Bared residents were not seen as victims but as perpetrators who had allowed a militant group to gain a foothold in the camp. This served to securitize reconstruction and made the army fill dual roles as conflict actor and urban planner. The primary data for this article were collected as part of documentary filmmaking during the site clearance and planning phase (2008-9), followed by field visits and taped interviews with displaced refugees in Nahr al-Bared and Beddawi camps during the initial reconstruction phase (2010-11). The ensuing reconstruction period (2012-17) combines secondary data and interviews with UNRWA and PLO officials, local activists, and others involved in rebuilding the camp.

\section{Rebuilding Nahr al-Bared?}

Today Lebanon is host to twelve official refugee camps under management by UNRWA. The Palestinian refugees were denied civil rights from the start, and their socio-political segregation was manifested by establishing new refugee camps in the outskirts of the capital, Beirut, and coastal cities. Most camps were located at a distance from urban centres and in some cases planned, in other cases built around former refugee settlements and army barracks. 39 The majority of the Palestinians have since remained camp based ( $52 \mathrm{per}$ cent) - the highest in the region - a result of non-integrative policies to prevent their permanent settlement (tawteen). ${ }^{40}$

In Lebanon rebuilding refugee camps is especially sensitive, because they embody critical governance issues that prevent their permanent settlement, and sensitive sectarian and security issues, which, after 1990, have made camps associated with lawlessness, expressed in the term "security islands" (juzur amniyya, "islands of [self-policed] security"), meaning that they are beyond the reach of Lebanese law, harbouring weapons and sheltering criminals. The refugee camps are self-governed and autonomous, and factions inside camps are armed-privileges granted in response to PLO military strength in the period prior to the civil war (1975-90) forming a part of the "Cairo Agreement" (1969).41 Attempts to repeal these privileges, especially to disarm factions and decommission arms, have been unsuccessful, although the original Cairo Agreement was abrogated by parliament in 1987. This means that refugee camps are under multiple, competing, and often conflictual governance by the state, security agencies, the army, UNRWA, and the camps' multiple leaderships, parties, armed factions, and Palestinian factions ("Popular Committees"), giving rise to a system of "hybrid sovereignties." ${ }^{42}$ The governance of Palestinian refugee 
camps depends on their history and location. The northern camps, especially those clustered around Tripoli, such as Beddawi and Nahr al-Bared, were traditionally under Syrian stewardship following the defeat and evacuation of PLO forces from North Lebanon in 1982. ${ }^{43}$ Until 2007 Nahr alBared was the most open, peaceful, and prosperous camp in the country and enjoyed close relations with neighbouring communities through its role as a central marketplace, with a large informal economy, cheap labour, goods, and services, as well as close to the highway connecting the rural Akkar region with Tripoli, the regional capital.

The 2007 siege and destruction of Nahr al-Bared, the first during peacetime, was a turning point in the state's relation with Palestinian refugees that had steadily improved following the creation of the Lebanese Palestinian Dialogue Committee (LPDC) in 2005, a ministerial committee to manage refugee affairs. ${ }^{44}$ The Nahr al-Bared disaster was a political setback that verified long-held claims that the refugee camps are a security threat and shelters militant groups operating under foreign command. Rebuilding the camp also challenged the official policy of preventing permanent settlement of refugees in Lebanon, and was important enough to be inscribed into the Taif Agreement that ended the civil war, as well as in the preamble to the Lebanese constitution. The government and refugees reject "settlement" in Lebanon, but the camp's reconstruction involves refugees being "re-settled," with the connotation of implantation, and that is why groups in government opposed reconstruction and sought to delay it. ${ }^{45}$

The government was adamant that the new camp should not become a base for militant groups again. To this end, the rebuilt camp would not be administered by Popular Committees, as in most refugee camps, but, for the first time, be a Lebanese-administered camp controlled by the army. The plan involved construction of an army and naval base with a staff of about one thousand men stationed inside the camp perimeters (figure 3). The army's plan for community policing was rejected by the residents, ${ }^{46}$ seen as proof of the strict security regime to be enforced in the rebuilding of Nahr al-Bared-in official parlance a "model" that could be expanded to include other camps. ${ }^{47}$ This would not only open the thorny issue of autonomy and camp governance but was also seen as a return to the 1960 os control of refugee camps by the army intelligence agency, the "Deuxième Bureau," 48 and make the army the camp's final arbiter.

Almost fifty donors contributed to the early relief and recovery phase costing close to Us $\$ 125$ million (2007-11), but UNRWA, which was responsible for the humanitarian assistance to the displaced refugees, struggled to maintain adequate support. ${ }^{49}$ Rebuilding the camp and its infrastructure is costly and complex, comparable to constructing a midsized town. In 2008 Lebanon organized a donor conference in Vienna to raise money for rebuilding the camp. ${ }^{50}$ Since then the costs of reconstructing have continued to rise and now stand at US $\$ 345$ million if pre-construction operations are included. An additional US\$116 million is needed to rehabilitate adjacent (non-refugee) municipalities damaged during the army siege, bringing the total sum to around us $\$ 450$ million. By mid-2013 the twenty-eight donors had disbursed US $\$ 171$ million, including a multi-donor trust fund, leaving more than Us $\$ 150$ million for the camp's reconstruction. ${ }^{51}$ When completed the Nahr al-Bared camp would be one of UnRwAs largest rebuilding projects outside Palestine and Gaza. During previous camp disasters, one of the destroyed camps was not rebuilt. ${ }^{52}$ Among the refugees, there was suspicion that this camp too would not be rebuilt for lack of money and political opposition, especially from Maronite groups objecting to the Palestinian presence in the country. ${ }^{53}$ Despite government assurances to the contrary, refugees distrusted the pledge to rebuild the camp. The lingering uncertainty was made worse by subjecting those allowed to return to their homes in the ruined camp to a security regime that was stricter than that applied to the unruly camps in the south.

\section{Cordoning the Camp}

From late 2007, the ruined Nahr al-Bared camp was cordoned off with a wire fence interspersed by five army checkpoints (figure 3). To enter the camp, all residents above the age of thirteen had to carry an identity card and hold a residency permit. The residency permits were issued at the discretion of the army's Directorate of Military Intelligence and could be denied or left pending without reason and subject to change without prior notice at the discretion of army personnel..$^{54}$ Non-resident refugees could obtain visitor permits following a similar procedure. Additional permits, so-called work permits, were needed to access specific sections of the camp, the destroyed Old Camp, and the so-called Adjacent Area ("New Camp"). The permit system was premised on the fact that although the army's siege ended in September 2007, the camp has since been a de facto military zone, a measure that according to the Lebanese constitution (article 65, paragraph 5) requires a cabinet decree followed by parliament approval. Even though no such approval exists, the camp will be managed a designated military zone until reconstruction is finished. ${ }^{55}$

The residents were routinely harassed at checkpoints and their personal belongings scrutinized. The security regime made living in the camp so difficult that residents despaired and felt demonized. In the words of a local activist, "Why are they treating us like terrorists; why, why?" ${ }^{56} \mathrm{He}$ had earlier been arrested and detained after criticizing the army's heavyhanded security in a TV newscast. He was released two days 


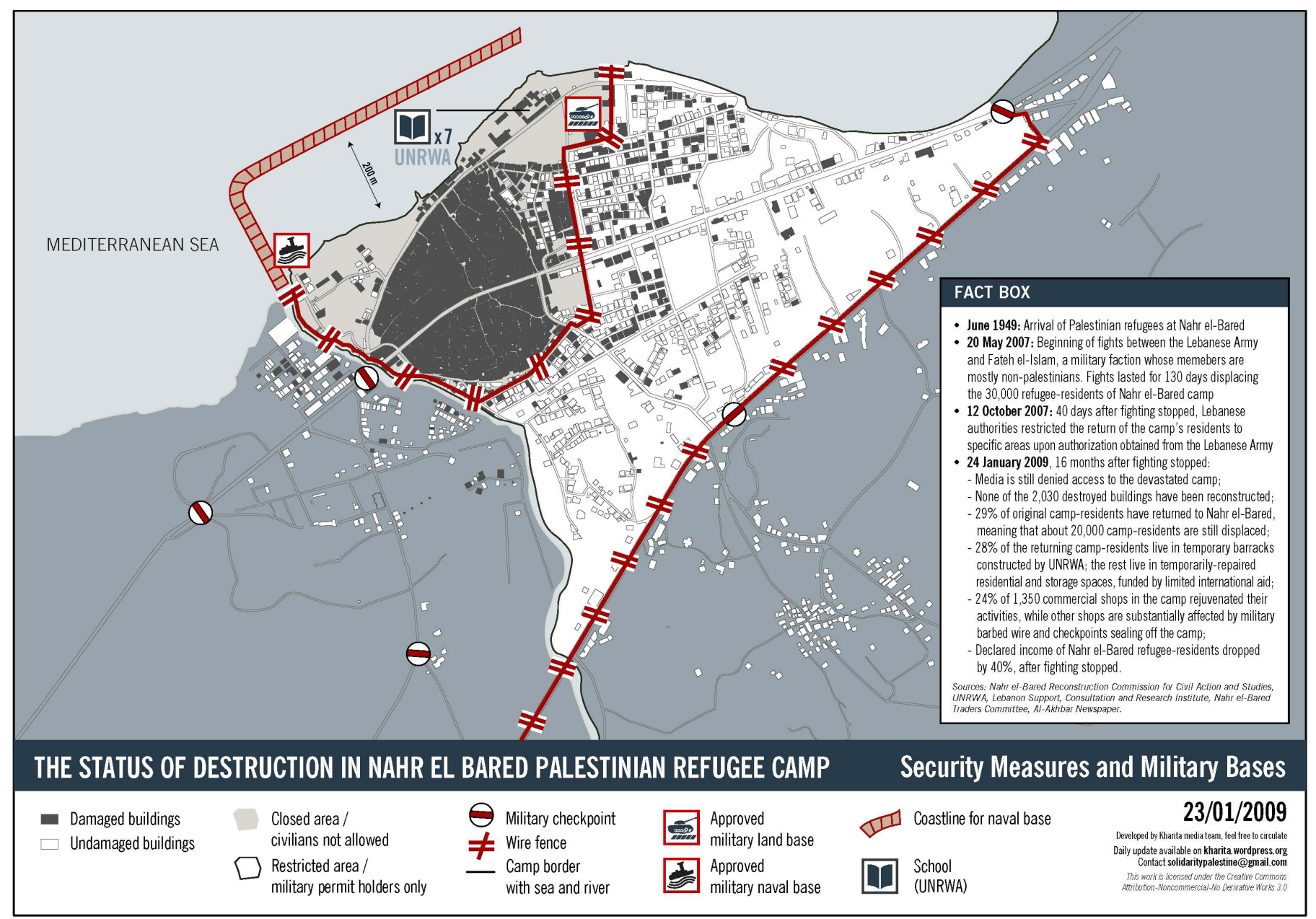

Figure 3. Nahr al-Bared: Security measures and military bases, 2009

Reproduced under licence CC BY NC ND 3.0, https://kharita.files.wordpress.com/2009/o1/nahr-el-bared.pdf.

later, on condition that the interview was deleted, yet he continued to face harassment and intimidation. Another contact had similarly been detained after writing a critique in a local daily of the army's role in cordoning the camp. These examples underline the strict security that applied to the camp and the harassment of those criticizing the army's post-conflict role. These restrictions are significant because the army is one of Lebanon's most trusted public institutions, and in carefully protecting its neutrality it avoids taking sides in conflicts. ${ }^{77}$ However, sensitive to its public image, the army silenced the critique of the siege of Nahr al-Bared, furthering government "obsession with security," which slowed the camp's reconstruction..$^{58}$

At the time, most of the camp's residents were displaced and living in makeshift shelters or shared and rented rooms. The few who had been allowed to return were forced into debt to repair their homes or to rent temporary housing. The worst off were the about 1,00o persons languishing in temporary shelters-"metal housing units" measuring only eighteen square metres-without air-conditioning stacked on the edge of the camp, appropriately nicknamed "Guantanamo 2." Hot, humid, and drab, the shelters are filled with tired and depressed adults, wide-eyed youngsters, and bored youth killing time playing cards. ${ }^{59} \mathrm{Nahr}$ al-Bared had become a hyperghetto where the residents suffered from strict surveillance and segregation in what could be called a "permanent state of emergency." 60 The displaced refugees were adamant that the army's target was not Fatah al-Islam but getting even with the refugees believed to be complicit in hiding, supporting, and abetting the militants. The real target was the refugees themselves, not Fatah al-Islam. Ruining the camp was a collective punishment of the refugees, not a military tactic dictated by the need to confront Fatah al-Islam. 
For the first-generation Palestinian refugees who lost their home and property in the 1948 Arab-Israeli war, commonly referred to as the disaster (al-Nakba), the loss is even deeper. The Nahr al-Bared destruction is interpreted as a second disaster. Many of the first- and second-generation refugees living in Nahr al-Bared have experienced repeated war and displacement. The attack on the camp brought back painful civil war memories: the destruction and flight from the Tell al-Zatar refugee camp (1976), the massacres in Sabra and Shatila (1982), and the brutal War of the Camps (1985-7). The destruction of the Nahr al-Bared camp was therefore seen as a continuation of the attack on Palestinians in Lebanon facing decades of legal discrimination, marginalization, and repeated displacement. ${ }^{61}$ In the words of a young Palestinian from the camp, "We, the Palestinians, really do not have any rights. We are oppressed, but why? Is it because we have this blue ID-card? Or because we are refugees? Or because we live in camps, in slums [zinco]? But I feel proud of being a Palestinian. You and others might hear me, but those who should give me my rights are not listening to me. They ignore me because I am a Palestinian." ${ }^{6}$

\section{Securitizing Reconstruction}

The original master plan for rebuilding the Nahr al-Bared camp sought to extend the military's role in determining the layout of the camp's reconstruction. In order to ease access and surveillance, the army wanted Nahr al-Bared rebuilt with low-rise apartment blocks separated by streets that were ten to fifteen metres wide. This is a securitized model of urban planning that breaks with the original camp layout, which is modelled on an army camp with barracks. ${ }^{63}$ Moreover, the army opposed balconies and banned basements; the new houses should have neither because they could be used by armed groups. ${ }^{64}$ In order to prevent the new homes from becoming future bases in an armed insurrection, they are constructed using a "floating slab foundation," where concrete is poured onto the construction site with minimal topsoil removal (figure 4).

This building technique avoids digging deep into the ground, which could potentially harm archaeological remains but, more importantly, prevents access to the many underground bunkers that were excavated during the civil war. The bunkers were one reason why the army took so long dislodge Fatah al-Islam. The floating slab foundation was chosen to securitize the camp's reconstruction and prevent the camp from becoming an insurgent base. Hence the army sought to transform the camp from a potential "zone of outlaws" to a military "zone of security" where the residents had minimal influence on their urban space. In this sense, the army emerged as an urban planner, stewarding

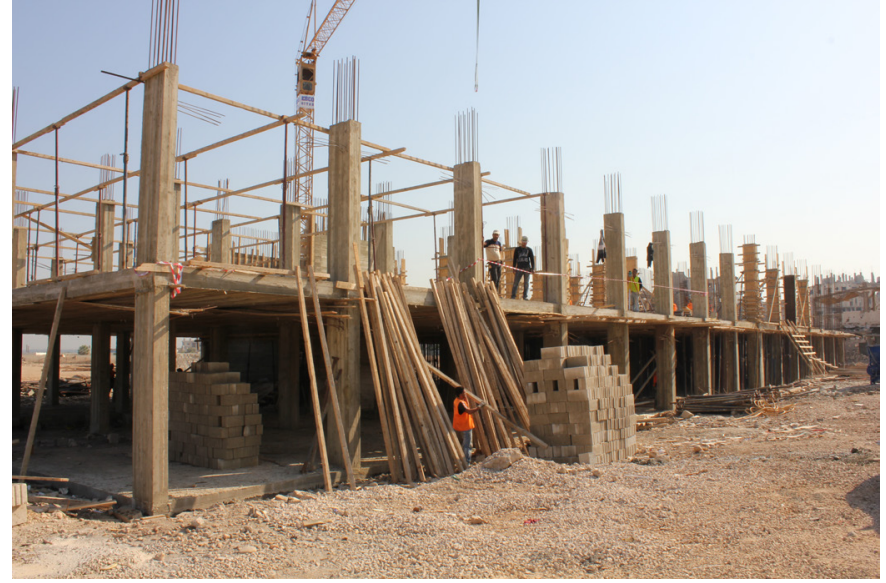

Figure 4. Floating slab foundation used in reconstructing Nahr al-Bared, 2011

(C) Mahmoud Zeidan, reproduced with permission

reconstruction based on a militarized design that privileges security and policing.

One of the most complex issues for rebuilding the camp, in addition to the lack of money, was the complex property ownership that surrounds both the plots and individual housing units. ${ }^{65}$ Most residents did not hold formal deeds of ownership to their houses or plots. Many of the houses and flats had changed owners several times, or absentee owners had put flats on long-term lease, but without legally valid registration. This is a common practice in Lebanon, reflecting the pervasive informality of the housing and property market. ${ }^{66}$ The 2001 amendment, which barred Palestinian refugees from owning or registering property, made the process even more difficult and time consuming. ${ }^{67}$ Additionally, the destroyed camp is divided into two sections that not only reflect the territorial expansion from the original unRwA Old Camp to the adjacent New Camp, but also from houses located on land leased by UNRWA, to land where the houses are squatting on private and municipal land. Thus, complex ownership issues surrounding apartments, housing blocs, and plots, and necessitated expropriation of land need to be resolved. ${ }^{68}$

\section{Participatory Planning?}

In order to counter the original plans for rebuilding the camp and establish a baseline for rebuilding houses, a grassroots initiative was formed around a young Palestinian architect turned activist. ${ }^{69}$ Initially the upstart Nahr al-Bared Reconstruction Commission for Civil Action and Studies was ignored by the government, UNRWA, and local powerbrokers in the camp. ${ }^{70}$ Undaunted, the commission inserted itself squarely into the planning process to document property 
ownership, influence the reconstruction, and especially challenge the initial draft for the master plan that would turn housing blocs into barracks and alleyways into autostradas. The commission surveyed the ruined buildings and, with the help of the destitute families, sorted out property ownership and drew up detailed plans for individual housing units. ${ }^{71}$ More than 150 volunteers helped with "asset-mapping," using large-scale walk-in maps to assist residents with identifying their houses and those of their neighbours. This painstaking work included almost 1,700 buildings and was critical enough for UNRWA's Camp Improvement Program (CIP) to include the commission in a joint planning and design unit comprising four chief architects leading more than eighty support staff liaising with the UNRWA HQ developing the overall design for the camp and individual apartments. ${ }^{72}$ After two years of work, more than sixty design meetings with officials and submission of twenty-four different versions of the master plan, the preliminary plan was finally approved by the government in May 2009. ${ }^{73}$ Says a camp manager, "The system was very tightly controlled and demanding, with frequent controls and monitoring. All plans, drawings and work packages had to be approved and the [the buildings'] size and height had to comply with the plan. The Master Plan was the 'red line' and when agreed to by the army, UNRwA, and the government, it had to be adhered to."

This was the first time UNRwA agreed to work in partnership with a grassroots organization.74 The most important part of this participation was to "recreate the social geography of the camp, reproducing the original street and public space layouts as well as the footprints of the various buildings." 75 The urban design was based on the extended family unit with mostly three-storied residential blocs, 76 but the master plan reduced the footprint of individual housing units by $15-35$ per cent to provide more public space (increased from 13 to 37 per cent) but also to accommodate the army's demand for wider streets. ${ }^{77}$ This meant rehousing refugees in smaller apartments, with smaller families taking the biggest reductions, creating resentment and charges of favouritism and corruption. ${ }^{78}$

However, before construction could begin, UNRWA had to validate the information and ensure that the plan complied with national building regulations. The validation process alienated the refugees, who were turned from participants to clients, with UNRWA reasserting control of the reconstruction. ${ }^{79}$ At the same time, the commission began to crumble following internal divisions and growing opposition from Popular Committees, which ignored it at first, later considered it a competitor, and finally decided to replace it. ${ }^{80} \mathrm{In}$ the spring of 2010 the commission closed operations and the main protagonist left. This not only ended the participatory planning between the commission and UNRWA's design unit but also made political factions, weakened by loss of authority and trust, the new counterpart in the camp's reconstruction. The collapse of the commission was UNRWA's loss too, as the agency no longer benefited from liaising with a politically independent body. ${ }^{81}$

In early 2009, almost two years after the camp's destruction, bulldozers finally began removing the rubble and unexploded ordnance that littered what used to be the Old Camp. In March an inaugural ceremony was held to mark the laying of the foundation stone for the new camp. Nonetheless, rubble removal was halted after archaeological remains were unearthed, only to be restarted a couple of months later. Reconstruction continued at a snail's pace, mostly on temporary shelters and repairs. In the New Camp that falls outside the original camp perimeters under management by UNRWA, the majority were still awaiting permission to move back to their severely damaged but still habitable homes located adjacent to the camp in the "Prime Areas" zoned from A through $\mathrm{E}$. The original deadline for completing the camp's reconstruction was in 2011, but by then Nahr al-Bared's slow and erratic reconstruction had caused enormous frustration, resentment, and, in the end, public protests and demonstrations. ${ }^{82}$ The militarized security regime had made the camp one of the most difficult places to live in Lebanon and discouraged many from returning. Still, those displaced remained emotionally attached to the camp and wanted to return: "I don't know how to express it, but I prefer to live in Nahr al-Bared, whatever the situation, even in the presence of Lebanese soldiers and security fences." ${ }^{\prime 3}$

\section{Rebuilding Camp and Community?}

The many delays, false starts, and planning hurdles had made people despair and lose faith. In late September 2011, after an agonizing four-year wait, the first of eight reconstruction "packages," P1 housing 317 families and three UNRWA schools were inaugurated during an official ceremony (figure 5). On this occasion, invited guests where whisked past checkpoints by courteous army personnel checking IDs and printed invitation cards. Inside the camp, smiling UNRWA employees distributed white baseball caps sporting the UNRWA logo and provided a lavish, colour portfolio of the Nahr al-Bared reconstruction project titled "Peace Starts Here." The inauguration ceremony was held under the patronage of the Government of Lebanon and included speeches by ministers, UNRWA officials, as well as Palestinian representatives in the presence of donors, ambassadors, UNRWA representatives, and UNRWA staff seated in the front rows next to the outdoor scene erected for the event (figure 5). ${ }^{84}$ The carefully staged event included speeches, appeals, popular song and traditional dance performances by a Palestinian youth troupe, all captured by film crews and journalists. 
Next to the podium, activists from the camp's political factions held up placards listing demands that the government end the permit system, rebuild the remainder of the Old Camp, and arrange for UNRWA to fund emergency relief and provide temporary shelters (figure 5). To underline the urgency of their demands, they chanted impromptu couplets subtly shaming the prominent speakers:

O' government ... where are you, where are you? And the [army's security] permits are in front of your eyes!

O' government ... where are you, where are you? And the [PLO] ambassador is in front of your eyes!

O' the PLO ... where are you, where are you? And the eight million [dollars promised as funding] are in front of your eyes $!^{85}$

Behind them a huge poster publicized the event: "Nahr alBared: Rebuilding a Community" (figure 5). Still, the camp's erstwhile community, its residents, was literally offered the backseat. Separated from the guests of honour by a green ribbon, the rows to the rear had been reserved for them. Only a few showed up, not for lack of interest, but because only a limited number had been allowed to take part. Aghast, many stayed away, feeling snubbed. ${ }^{86}$ One distraught woman in the back rows repeatedly tried to break into the front lines where UNRWA officials and invited speakers were seated, only to be restrained by army personnel. This division points to much deeper tensions between UNRWA's celebratory inauguration ceremony "Rebuilding a Community" and the desperation of displaced refugees at the end of their tether. It suggests that the "participatory approach" ended when the planning phase was completed in 2009 and UNRWA reasserted control of reconstruction, reverting to its default central planning mode that alienated the displaced refugees.

\section{Contested Reconstruction}

Despite completion of the first reconstruction package, the residents were fed up with the living conditions in the camp and suffered from stress, frustration, and anger. In mid-June 2012 a new round of protests broke out in the camp. At one army checkpoint, a quarrel over entry permits led to army guards killing a fifteen-year-old boy. ${ }^{87}$ With the camp's cemetery already filled beyond capacity, burial was impossible within the confines of the camp. The next day the victim's body was taken for burial on a piece of land owned by the PLo but controlled by the army. When the army intervened to stop the burial, fighting broke out and the soldiers on duty, claiming to be under attack, fired into the crowd, killing two and injuring twenty. ${ }^{88}$ These incidents sparked countrywide protests and provoked clashes, strikes, and sit-ins in support of the victims. The situation in the Nahr al-Bared camp long remained tense, with the army claiming that it had been "infiltrated" by pro-Syrian elements

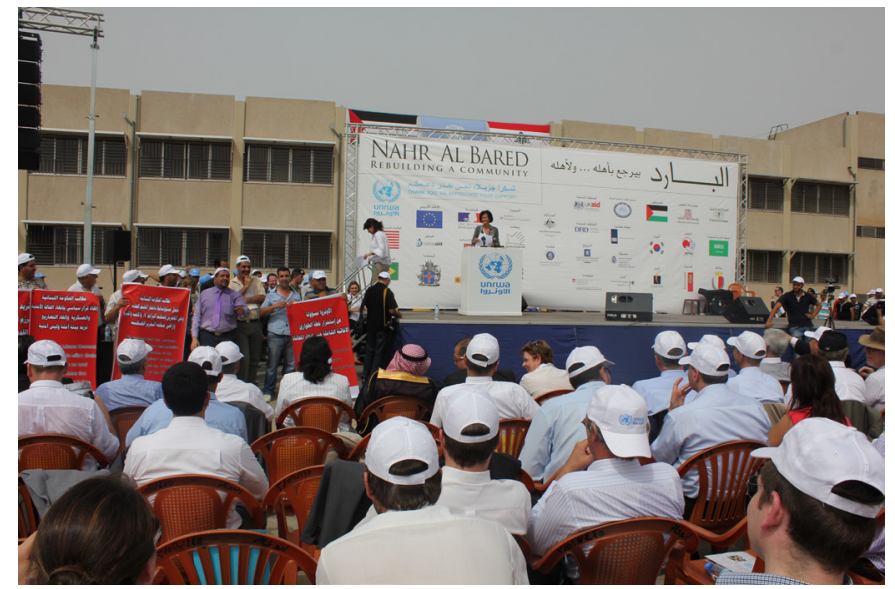

Figure 5. Nahr al-Bared inaugural ceremony (Package 1), 2011 Source: Photograph by the author

seeking to provoke strife and destabilize the country. Later, bowing to pressure, the army lifted the camp's permit system from mid-July 2012, but other entry restrictions remain in place, and the checkpoints are still manned by the army. ${ }^{89}$ Says an UNRWA camp manager, "The camp is a weapons-free zone, but the army is still controlling the camp. Since 2014, the army has withdrawn and is less visible, but has a well-developed intelligence-gathering system in the camp-they know what is going on and pretty much run everything." ${ }^{\prime 0}$

In mid-2013 reconstruction stalled again amidst new funding shortfalls, prompting demonstrations in front of UNRWA's head office in Beirut. ${ }^{91}$ The fact that only two smaller sections (packages) of the Old Camp had been rebuilt by then was proof that the reconstruction of the camp was a hoax. The contract for clearing the building site and reconstruct the camp was first awarded to the Lebanese firm Al-Jihad Associates, but after delays and extensive subcontracting, it was transferred to another contractor, Danash. Although the main contractor is Lebanese, most of the labour force is Palestinian. ${ }^{92}$ For UNRWA, managing the many donors was time consuming, with most channelling funds outside the multi-donor trust fund set up for the purpose, as was matching them with contractors. In the words of a UNRWA camp manager, "In the first phase, we outsourced too much work to large contractors which subcontracted the work, resulting in poor quality. This gave us a problem and made us lose control of the reconstruction." Following an internal audit in 2013-14, UNRWA decided to downsize the reconstruction unit, laid off non-essential staff, outsourced less work, and gave out only smaller tenders. ${ }^{93}$

In 2013 the Nahr el-Bared master plan was shortlisted for the prestigious Agha Khan Architecture Award and, a year later, nominated for the City-to-City Barcelona award. 
However, the camp's urban design had reduced the size of homes by one-third on average, to accommodate enlarged public space, gardens, wider alleys, and access roads. The residents, however, preferred larger homes but had to contend with a net reduction in their living space. Like in camps elsewhere in Lebanon, enlargements and adding new top floors are prohibited, although the rule is frequently circumvented, leaving families without legal options for enlarging homes and accommodating new family members. ${ }^{94}$ After ten years, the returning families' size and composition had changed, leaving many dissatisfied with their new homes.

By October 2015, UNRWA could no longer afford to pay rental cash subsidies (US\$150) to the close to 2,200 displaced families renting temporary premises elsewhere: "The donors would no longer provide humanitarian aid almost ten years into the post-conflict phase." ${ }^{95}$ As foreign funding dwindled, key services were also reduced, especially health care, prompting long and angry protests from the refugee community, including the closure of construction sites. Between 2013 and 2015, violent clashes in Tripoli prevented access to the camp and further delayed reconstruction. Inside the camp, local commerce had not rebounded because army checkpoints discouraged traders and customers alike. Reconstruction had also stalled as the result of funding shortages, with about Us $\$ 100$ million needed to finalize the remaining three reconstruction packages. ${ }^{96}$ The massive funding needed for the Syrian displacement crises (2012-present) had made funding even scarcer, but Lebanon was able to get additional funds for the Nahr al-Bared reconstruction (US\$50 million) as part of the Syria Pledging Conference in London in 2016. ${ }^{97}$ In 2016, UN Secretary Ban Ki-Moon visited the camp and urged donors to fund the camp's reconstruction, 98 but the deadline for completion kept being extended. By the end of 2017 about half of the housing units had been completed, while another 370 housing units were under construction (table 1). ${ }^{99}$ In the words of an UnRwA camp manager, "We are committed to rebuild the camp, especially for those still living in temporary shelters. We are also bound by the Vienna document and our responsibility to the refugee community." ${ }^{100}$ While the Vienna document put UNRwA in charge of the Nahr el-Bared reconstruction, even by 2012 this arrangement had had not been formalized in a memorandum of understanding between the government and the agency. ${ }^{101}$ Also unresolved was UnRWAs post-reconstruction role in a camp built by donor money on expropriated land. ${ }^{102}$ By March 2018, UnRwA had received US $\$ 238$ million and estimated that reconstruction could be completed in two years if the remaining funding was secured. ${ }^{103}$ However, withdrawal of U.S. funding to UNRWA in August 2018 and the loss of one-third of its budget could further delay reconstruction of Nahr al-Bared, despite the agency's efforts to compensate for the loss. ${ }^{104}$

\section{Conclusion}

The Nahr al-Bared refugee camp was destroyed and its populace displaced in one of the largest internal battles in postcivil war Lebanon. The army's victory was achieved at very high human costs and at the expense of the displaced refugees. In this article I have argued that the destruction of the camp laid the foundations for its contested reconstruction and illustrates the obstacles to urban planning and reconstruction in a militarized "space of exception." The piecemeal reconstruction was subject to army dictates, which influenced the new camp's layout (access roads), construction technique (slab foundation), and design principles (maximum height, facades), and introduced new governance and security regimes vested with the army (community policing).

The design for the new camp was a milestone in the participatory planning of a refugee camp, but the contractordriven reconstruction faced many obstacles-financial, bureaucratic, governmental-meaning that delays were inevitable. The 2006 July War reconstruction used ownerdriven and contractor-driven approaches in South Lebanon and Beirut respectively, but the Nahr al-Bared reconstruction relied solely on the latter. A mixed or hybrid approach, combining the two, ${ }^{105}$ could have sped up reconstruction of Nahr el-Bared, but judicial, political, and security concerns prevented this from being an option. Stewarding reconstruction on behalf of the displaced refugees pitted UNRWA against the army, doubling as a conflict actor and urban planner. Because of the contested nature of the camp's destruction and fear of upstaging the consensus on "non-settlement" of refugees, UNRWA could neither steer the camp's reconstruction outside bureaucratic channels nor disregard state directives in the manner of powerful patrons-cum-planners such as Hizbollah. UNRWA-a humanitarian agency dependent on donations and chronically underfunded-juggled close to thirty reconstruction donors, with about one-third donating less than one million dollars. Handling the large number of donors was time-consuming and more so, because most avoided channelling funds through the multi-donor trust fund, which added to the stakeholder bureaucracy, as did managing funds for emergency relief to the displaced refugees. Together this overwhelmed UnRwA's capacity and mandate.

The widespread housing informality added another layer of complexity for UNRWA, having to sort out ownership and rehouse refugees on a smaller area. Indeed, rehousing residents in smaller apartments violated UNRWA's camp improvement policy of "rebuilding what was lost," although 
the apartments were better planned and constructed and had more available light. Once planning ended, UNRwA reverted to the top-down approach that alienated the displaced refugees. The master plan's urban design was an attempt to reconcile home and security, but the most fundamental planning principle was not the refugees' needs and rights, but the army's demand for security that would ease policing and surveillance in the camp, since 2007 a designated "emergency zone." The army's main objective was to prevent militant groups from regaining a foothold in the camp. The huge loss of life to army servicemen during the siege of the camp further increased the need to securitize reconstruction. The combined security and financial constraints accounted for massive delays in rebuilding the camp that in a decade have left half the residents still homeless. In glaring contrast to the swift July War reconstruction, this demonstrates the exceptionality of refugee camps and the human costs of failing to rebuild the Nahr al-Bared camp in a timely manner that subjected the displaced refugees to a "decade of despair."

\section{Acknowledgements}

I would like to thank Palestinian and Lebanese friends, collaborators, and activists who facilitated research in Nahr al-Bared and shared information on the camp's lengthy reconstruction. A special thanks to Kjersti Berg and the journal's two anonymous reviewers for detailed comments on a previous version. Remaining errors are solely my own responsibility. Permission to reproduce images copyrighted by UNRWA and the International Crisis Group (ICG) is gratefully acknowledged. This article is dedicated to the memory of the late Ahmad Miari-Nahr al-Bared refugee, activist, and volunteer.

\section{Notes}

1 Government of Lebanon (hereafter GoL), A Common Challenge, a Shared Responsibility: The International Donor Conference for the Recovery and Reconstruction of the Nahr El-Bared Palestinian Refugee Camp and Conflict-Affected Areas of North Lebanon, Vienna, June 23, 2008 (Beirut: Government of Lebanon, 2008), 19.

2 Are Knudsen, "Nahr El-Bared: The Political Fall-out of a Refugee Disaster," in Palestinian Refugees: Identity, Space and Place in the Levant, ed. Are Knudsen and Sari Hanafi, 97-110 (London: Routledge, 2011).

3 International Crisis Group, "Lebanon's Palestinian Dilemma: The Struggle over Nahr Al-Bared ," Middle East Report 117, 1 March 2012, 3.

4 The Nahr al-Bared camp consist of two sections; the original "Old Camp" (o.2 square kilometres, population 20,000) managed by the United Nations Relief and Works Agency for Palestine Refugees in the Near East (UNRWA), and the adjacent "New Camp" (1.6 square kilometres, population
7,000). The New Camp is a non-camp extension under Lebanese jurisdiction with a mixed Palestinian and Lebanese population. See GoL, Common Challenge, 19-20.

5 GoL, Common Challenge, 29-30.

6 GoL, Common Challenge, 19.

7 PLO Ambassador to Lebanon, interview, Beirut, 5 February 2008; Hamas representative in Lebanon, interview, 25 March 2009.

8 Are Knudsen, "(In-)Security in a Space of Exception: The Destruction of the Nahr El-Bared Refugee Camp," in Security and Development, ed. John-Andrew McNeish and Jon Harald Sande Lie, 99-112 (Oxford: Berghahn, 2010).

9 Mahmoud El Ali, "Overview of Palestinian Forced Displacement in and from Lebanon 1948-1990," al majdal 44 (Summer 2010): 22-8.

10 Nadim Shehadi, A Staircase in Nahr El Bared: The Future of Palestinian Refugees in Lebanon (Washington, DC: Aspen Institute, 2010), 13.

11 Philipp Misselwitz and Sari Hanafi, "Testing a New Paradigm: UnRWA's Camp Improvement Programme," Refugee Survey Quarterly 28, no. 2-3 (2009): 360-88.

12 Many camps have population densities above 100,000 persons per square kilometre. Henri Rueff and Alain Viaro, "Palestinian Refugee Camps: From Shelter to Habitat," Refugee Survey Quarterly 28, no. 2-3 (2009): 339-59, 358.

13 UNRWA, "Where We Work," https://www.unrwa.org/ where-we-work/lebanon.

14 Nell Gabiam, "When Humanitarianism Becomes Development: The Politics of International Aid in Syria's Palestinian Refugee Camps," American Anthropologist 114, no. 1 (2012): 95-107; Misselwitz and Hanafi, "Testing a New Paradigm" $360-88$.

15 Linda Tabar, "The Urban Redesign of Jenin Refugee Camp: Humanitarian Intervention and Rational Violence," Journal of Palestine Studies 41, no. 2 (2012): 44-61.

16 This can be traced to the 1950 os West Bank Shelter Program, where the size, location of houses, and support functions were defined by strict zoning principles, and blocs and units were served by wide access roads. See Misselwitz and Hanafi, "Testing a New Paradigm," 368.

17 Tabar, "Urban Redesign of Jenin Refugee Camp," 47.

18 Misselwitz and Hanafi, "Testing a New Paradigm," 371.

19 Fatima Al-Nammari, "When the Global Impacts the Local: Revisiting Talbiyeh Camp Improvement Project," Habitat International 44 (2014): 158-67.

20 Giorgio Agamben, Homo Sacer: Sovereign Power and Bare Life (Stanford: Stanford University Press, 1998); Agamben, State of Exception (Chicago: University of Chicago Press, 2005).

21 Adam Ramadan, "Spatialising the Refugee Camp," Transactions of the Institute of British Geographers 38, no. 1 (2013): 65-77; Patricia Owens, "Reclaiming 'Bare Life'? Against Agamben on Refugees," International Relations 23, no. 4 (2009): 567-82; Leonardo Schiocchet, "Palestinian 
Refugees in Lebanon: Is the Camp a Space of Exception?" Mashriq \& Mahjar 2, no. 1 (2014): 130-60.

22 Sari Hanafi and Taylor Long, "Governance, Governmentalities, and the State of Exception in the Palestinian Refugee Camps of Lebanon," Journal of Refugee Studies 23, no. 4 (2010): 134-59.

23 Adam Ramadan, "Destroying Nahr El-Bared: Sovereignty and Urbicide in the Space of Exception," Political Geography 28, no. 3 (2009): 153-63.

24 Lucas Oesch, "The Refugee Camp as a Space of Multiple Ambiguities and Subjectivities," Political Geography 60 (2017): 110-20. https://www.sciencedirect.com/science/ article/pii/So962629817301427?via\%3Dihub.

25 Ron Dudai, "Through No Fault of Their Own: Punitive House Demolitions during the Al-Aqsa Intifada," Human Rights Quarterly 28, no. 3 (2006): 783-95.

26 Rosemary Sayigh, "House Is Not a Home: Permanent Impermanence of Habitat for Palestinian Expellees in Lebanon," Holy Land Studies 4, no. 1 (2005): 17-39.

27 Sultan Barakat and Steven A. Zyck, "Housing Reconstruction as Socio-economic Recovery and State Building: Evidence from Southern Lebanon," Housing Studies 26, no. 1 (2010): 133-54; Howayda Al-Harithy, ed., Lessons in Postwar Reconstruction: Case Studies from Lebanon in the Aftermatch of the 2006 War (London: Routledge, 2010).

28 Barakat and Zyck, "Housing Reconstruction," 139.

29 Roger Mac Ginty and Christine Sylva Hamieh, "Made in Lebanon: Local Participation and Indigenous Responses to Development and Post-war Reconstruction." Civil Wars 12, no. 1-2 (2010): 47- 64 .

30 Christine Sylva Hamieh and Roger Mac Ginty, "Reconstructing Post-2006 Lebanon: A Distorted Market," in Rethinking the Liberal Peace: External Models and Local Alternatives, ed. Shahrbanou Tadjbakhsh, 181-94 (London: Routledge, 2011), 185.

31 Barakat and Zyck, "Housing Reconstruction," 139, 147.

32 Christine Sylva Hamieh and Roger Mac Ginty, "A Very Political Reconstruction: Governance and Reconstruction in Lebanon after the 2006 War," Disasters 34, no. 1 (2010): $102-23$.

33 Najib B. Hourani, "Post-Conflict Reconstruction and Citizenship Agendas: Lessons from Beirut," Citizenship Studies 19, no. 2 (2015): 184-99.

34 Mona Fawaz and Marwan Ghandour, The Reconstruction of Haret Hreik: Design Options for Improving the Livability of the Neighborhood (Beirut: American University of Beirut, Architecture Department Reconstruction Unit Document, 2007).

35 Mona Harb, "Faith-Based Organizations as Effective Development Partners? Hezbollah and Post-war Reconstruction in Lebanon," in Development Civil Society and Faith-Based Organisations: Bridging the Sacred and the Secular, ed. G. Clarke and M. Jennings, 214-39 (London: Palgrave, 2008).

36 Mona Fawaz, "Hezbollah as Urban Planner? Questions to and from Planning Theory," Planning Theory 8, no. 4
(2009): 323-34; Fawaz, "The Politics of Property in Planning: Hezbollah's Reconstruction of Haret Hreik (Beirut, Lebanon) as Case Study," International Journal of Urban and Regional Research 38, no. 3 (2014): 922-34.

37 The Waad project comprised four square kilometres; see Hana Alamuddin, "Wa'd: The Reconstruction Project of the Southern Suburb of Beirut," in Lessons in Post-War Reconstruction: Case Studies from Lebanon in the Aftermath of the 2006 War, ed. Howayda Al-Harithy, 46-70 (London: Routledge, 2010).

38 "Half Rebuilt, Nahr al-Bared Comes to Standstill over Funding Shortfalls," Daily Star, 5 June 2013, http://www.dailystar.com.lb/ArticlePrint.aspx?id=219447\&mode=print.

39 Rebecca Roberts, Palestinians in Lebanon: Refugees Living with Long-Term Displacement (London: I.B. Tauris, 2010), 77.

40 Daniel Meier, "Al-Tawteen: The Implantation Problem as an Idiom of the Palestinian Presence in Post-Civil War Lebanon (1989-2005)," Arab Studies Quarterly 32, no. 3 (2010): 145-62.

41 The Cairo Agreement provided administrative autonomy to the camps, lifted the ban on employment, and, for the first time, authorized Palestinian attacks on Israel from Lebanese soil. The agreement was abrogated throughout the civil war and lastly in 1987 , but the camps have remained de facto autonomous, with internal governance and security vested with political factions.

42 Adam Ramadan and Sara Fregonese, "Hybrid Sovereignty and the State of Exception in the Palestinian Refugee Camps in Lebanon," Annals of the American Association of Geographers 107, no. 4 (2017): 949-63.

43 Åge Tiltnes, "A Socio-economic Profile of the Nahr ElBared and Beddawi Refugee Camps of Lebanon," Fafopaper 200, 16.

44 Knudsen, "Nahr El-Bared." The LPDC's role as interlocutor steadily diminshed over the period and added to demands on UnRwa. See ICG, "Lebanon's Palestinian Dilemma," 10.

45 ICG, "Lebanon's Palestinian Dilemma," 18.

46 Residents of Nahr El Bared to Prime Minister Fouad El Siniora, Electronic Intifada, 27 January 2009, http://electronicintifada.net/v2/article10246.shtml.

47 Muhammad Ali Khalidi and Diane Riskedahl, "The Road to Nahr Al-Barid: Lebanese Political Discourse and Palestinian Civil Rights," Middle East Report 244 (Fall 2007): 26-9. Community or proximity policing is outlined as integral to the camp's governance. GoL, Common Challenge, 46.

48 Rex Brynen, Sanctuary and Survival: The PLO in Lebanon (Boulder, co: Westview, 1990).

49 UNRWA official, interview, Beirut, 25 March 2009.

50 From late 2007 UNRWA launched a series of emergency appeals to support the destitute refugees, followed by a donor conference in Vienna in 2008 to fund the camp's reconstruction. The reconstruction costs were to be shared 50:50 between Western and Arab donors. See GoL, Common Challenge. 
51 Sultan Barakat, Reconstruction of Nahr el-Bared Refugee Camp Tripoli, Lebanon (Beirut: UNRWA, 2013), 17.

52 Of the six southern camps destroyed during the 1982 Israeli invasion, five were rebuilt: Rashidiyye, Burj al-Shemali, alBuss, Ayn al-Hilweh, and Miyyeh-Miyyeh.

53 The Lebanese Forces Party (LFP) and the Free Patriotic Movement (FPM).

54 PHRO, Lebanese Restrictions on Freedom of Movement: Case of Nahr El Bared Camp (Beirut: Palestinian Human Rights Organization, PHRO, November 2010).

55 ICG, "Lebanon's Palestinian Dilemma," 2.

$56 \mathrm{Nahr}$ al-Bared resident, interview, Nahr al-Bared, 12 September 2008.

57 Are John Knudsen and Tine Gade, "Situating (In-)Security: A United Army for a Divided Country?" in Civil-Military Relations in Lebanon: Conflict, Cohesion and Confessionalism in a Divided Society, ed. Are J. Knudsen and Tine Gade, 1-22 (London: Palgrave Macmillan, 2017).

58 Commission member, personal communication, 5 December 2017.

59 Author's field notes, Nahr al-Bared, 15 September 2008.

60 Are Knudsen, "(In-)Security in a Space of Exception: The Destruction of the Nahr el-Bared Refugee Camp," in Security and Development, ed. John-Andrew McNeish and Jon H.S. Lie, 99-112 (Oxford: Berghahn, 2010).

61 Are Knudsen, Mahmoud Zeidan, and Jaber Suleiman, eds., Nahr el-Bared Talks Back, documentary film, 40 minutes, Arabic with English subtitles (Beirut, RedLine-Seven Media House, 2010).

62 Knudsen, Zeidan, and Suleiman, Nahr el-Bared Talks Back.

63 Commission member, interview, 10 May 2010.

64 Ismael Sheikh Hassan and Sari Hanafi, "(In)Security and Reconstruction in Post-Conflict Nahr al-Barid Refugee Camp," Journal of Palestine Studies 40, no. 1 (2010): 27-48.

65 UNRWA official, personal communication, Tripoli, 5 May 2010.

66 Nasser Yassin, Nora Stel, and Rima Rassi, "Organized Chaos: Informal Institution Building among Palestinian Refugees in the Maashouk Gathering in South Lebanon," Journal of Refugee Studies 29, no. 3 (2016): 341-62; Romola Sanyal, "How Refuge Creates Informality: Shelter Politics in Refugee Camps in Beirut," Jerusalem Quarterly 60 (Autumn 2014): 31-41.

67 Nadya Hajj, Protection Amid Chaos: The Creation of Property Rights in Palestinian Refugee Camps (New York: Columbia University Press, 2016).

68 Kuwait donated Us $\$ 13$ million to cover the costs of expropriating land. UNRWA camp manager, Skype interview, 9 April, 2018.

69 "Interview with Ismael Sheikh Hassan," ArteEast, Spring 2010, http://arteeast.org/quarterly/interview-with-ismaelsheikh-hassan/.

70 Commission member, interview, Beirut, 10 May 2010.

71 UNRwA, "Reconstruction of Nahr el Bared Palestine Refugee Camp in Northern Lebanon," presentation to
ARCHMARATHON Awards, October 2015, www.archmarathon.com/2015/tag/unrwa/.

72 Barakat, Reconstruction of Nahr el-Bared Refugee Camp, annex 1.

73 UNWA camp manager, personal communication, 6 April 2018; UNRWA, Preliminary Master Plan and Guidelines for the Reconstruction of Nahr El-Bared Palestine Refugee Camp (Beirut: UnRwA and Nahr el-Bared Reconstruction Commission for Civil Action and Studies, 2008). The planning process involved officials representing the Army, the Prime Minister's Office, the LPDC, and the Director-General of Urban Planning (DGUP).

74 UNRwA's chief architect and Deputy Director Musa Budeiri was also in charge of the Jenin-camp reconstruction. Misselwitz and Hanafi, "Testing a New Paradigm," 381.

75 John Whyte, "Realising Rights? Community Participation as a Means and an End: A Case Study of Two Urban Renewal Projects in an Inner-City Community in Ireland and a Palestinian Refugee Camp in Lebanon" (Dublin: MA thesis, Dublin City University, 2011), 44.

76 Sheikh Hassan, Urbanity of Exile.

77 Whyte, "Realising Rights?," 46.

78 Whyte, "Realising Rights?," 47.

79 Whyte, "Realising Rights?," 45.

80 PLO official, interview, Beirut, 9 May 2010.

81 ICG, "Lebanon's Palestinian Dilemma," 19.

82 "Palestinians to Protest Failure to Address Hardships of Nahr al-Bared Displaced," Daily Star, 20 May 2010, http://www.dailystar.com.lb/News/Lebanon-News/2010/ May-20/57559-palestinians-to-protest-failure-to-addresshardships-of-nahr-al-bared-displaced.ashx.

$83 \mathrm{Nahr}$ al-Bared resident displaced to Beddawi, interview, 13 September 2008.

84 Author's field observations, Nahr al-Bared, 28 September 2011.

85 Author's field recording, Nahr al-Bared, 28 September 2011.

86 Nahr al-Bared resident, interview, 28 September 2011.

87 Ismael Sheikh Hassan, "Palestinian Camp-Military Relations in Lebanon: The Case of Nahr al-Bared," in Civil-Military Relations in Lebanon: Conflict, Cohesion and Confessionalism in a Divided Society, ed. Are J. Knudsen and Tine Gade, 121-44 (London: Palgrave MacMillan, 2017).

88 "Three Palestinians Killed in Clashes with Army," Daily Star, 19 June 2012, http://www.dailystar.com.lb/News/Lebanon-News/2012/Jun-19/177311-three-palestinians-killedin-clashes-with-army.ashx.

89 Commission member, personal communication, 2016.

90 UNRWA camp manager, Skype interview.

91 "Half Rebuilt."

92 Commission member, personal communication, 8 October 2013.

93 UNRWA camp manager, Skype interview.

94 There are negotiations, yet unfinished, to allow new top floors but the owners must pay this themselves, as UNRWA is not responsible. 
95 UNRWA camp manager, Skype interview.

96 "Un Struggles to Rebuild Palestinian Refugee Camp," aljazeera, 14 February 2017, http://www.aljazeera.com/ indepth/features/2016/12/struggles-rebuild-palestinianrefugee-camp-161231140142502.html.

97 UNRWA, "Fulfilling the Promise: Completing the Reconstruction of Nahr el-Bared camp," memo, UNRwA Lebanon Field Office, April 2018.

98 "In Lebanon, un Chief and World Bank President Show Commitment to Leaving 'No One Behind," Office of the Secretary-General's Envoy and Youth, 26 March 2016, https://www.un.org/youthenvoy/2016/o3/lebanon-unchief-world-bank-president-show-commitment-leavingone-behind/.

99 "Reconstructing Nahr el-Bared: Completing the Task," UNRwA.org, 20 May 2017, https://www.unrwa.org/ newsroom/features/reconstructing-nahr-el-bared$\%$ E2\%80\%93-completing-task.
100 UNRWA camp manager, Skype interview.

101 ICG, "Lebanon's Palestinian Dilemma," 16.

102 UNRWA's position is that the agency's role is limited to service provision, while the government is responsible for day-to-day running of the camp. ICG, "Lebanon's Palestinian Dilemma," 16.

103 UNRWA, "Fulfilling the Promise."

104 Jaber Suleiman, "The Ongoing UnRwA Crisis: Context, Dimensions, Prospects and Responses" (Common Space Initiative, Policy Dialogue Series /o6, Beirut, 2018).

105 Barakat and Zyck, "Housing Reconstruction," 150-1.

Are John Knudsen is a senior researcher at the Chr. Michelsen Institute. The author can be contacted at are.knudsen@cmi.no. 